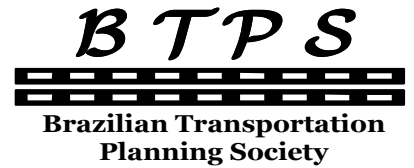

Planning Society
Journal of Transport Literature

Vol. 7, n. 4, pp. 8-22, Oct. 2013

Research Directory
JTL|RELIT

www.transport-literature.org ISSN 2238-1031

\title{
A generic decision model of refueling policies: a case study of a Brazilian motor carrier
}

[Um modelo de decisão para otimização da política de reabastecimento: um estudo de caso de uma transportadora rodoviária]

\author{
Amilton Dias Rodrigues Junior*, Marta Monteiro da Costa Cruz \\ Universidade Federal do Espírito Santo - Brazil
}

Submitted 22 Aug 2012; received in revised form 13 Jan 2013; accepted 20 Jan 2013

\begin{abstract}
Considering the high impact of the transport on the total logistics cost, the transportation management is fundamental to maintain the company's competitiveness. Particularly in Brazil, fuel represents a significant cost for the motors carriers. So, this paper presents the development of a generic mathematic model that optimizes the fuel cost and assists the company's decision making on refuelling policy choices. Basically, in order to reduce the total cost, this model analyses the fuel prices variations in a road network and, thereby, it define: (i) which truck stop(s) to use, and (ii) how much fuel to buy at the chosen truck stop(s). Therefore, to assist the development of this model, a set of publications was raised related to the techniques of refuelling optimization. As opposed to the papers analyzed, in which, the models are validated using simulations, the presented model uses a case study as a reference and, in this case, the model provided a decrease of $2.3 \%$ in total fuel cost.
\end{abstract}

Key words: logistics, fuel costs, linear programming, motors carriers, refueling problem.

\section{Resumo}

A administração do transporte é fundamental para a manutenção da competitividade das empresas, visto que o transporte tem um alto impacto nos custos logísticos totais. Em particular no Brasil, onde o combustível representa uma parcela significativa dos custos das transportadoras. Assim, esse artigo apresenta o desenvolvimento de um modelo matemático que otimiza o custo com combustível e auxilia na definição da polícia de reabastecimento das empresas. Basicamente, este modelo analisa das variações de preços dos combustíveis existentes em uma malha rodoviária, assim, ele define: (i) qual posto de combustível utilizar, e (ii) quanto de combustível deve ser abastecido em cada posto escolhido. Para auxiliar no desenvolvimento do modelo foram pesquisados vários artigos relacionados com a otimização da política de reabastecimento. Ao contrário dos trabalhos analisados, na qual os modelos são validades utilizando simulações, o modelo apresentado usa um estudo de caso como referencia e, neste caso, o modelo chegou a uma redução de $2,3 \%$ no custo total de combustível.

Palavras-Chave: logística, combustível, programação linear, transportadoras rodoviárias, problemas de reabastecimento de veículos.

* Email: rodriguesamilton@gmail.com.

\section{Recommended Citation}

Junior, A. D. R. and Cruz, M. M. C. (2013) A generic decision model of refueling policies: a case study of a Brazilian motor carrier. Journal of Transport Literature, vol. 7, n. 4, pp. 8-22.

- JTL/RELIT is a fully electronic, peer-reviewed, open access, international journal focused on emerging transport markets and published by BPTS - Brazilian Transport Planning Society. Website www.transport-literature.org. ISSN 2238-1031. 


\section{Introduction}

The transport cost in Brazil represents about $60 \%$ of logistics costs influencing the final price of the products and, consequently, the company's competitiveness. Thus, the transportation has an important role in the logistics process, because its cost contributes for a significant share of expenditure of the companies and influences the level of service provided (Nazario, 2000).

Academics works like Lima (2006); Lopes, Cardoso and Piccini (2008); and Rittiner and Manechini (2009) corroborate that the fuel is the main cost of the motors carriers. Lima (2006) showed that in 2004 the fuel cost represented $31,8 \%$ of the total cost and this value could achieve $41,8 \%$ according the total distance of the routes. In this same study, the author estimated that $55 \%$ of the total diesel consumed in Brazil during 2004 was used for cargo route transportation, corresponding around 21.7 billion liters or 32.7 billion BRL. According Rittiner and Manechini (2009), fuel is the main input for the motor carriers and represents on average $30 \%$ of total costs.

In a general way and particularly in Brazil this context is even intensified by the enormous variability of prices among different gas stations. According to the National Petroleum Agency (ANP), in 2010 the average variability in fuel prices was above $40 \%$.

Given this scenario, where the fuel cost has a significant impact on the logistics costs and price variances are higher, this paper will present an optimization model, based on linear programming, aiming to reduce the fuel cost for the motors carriers. This model was developed through a case study of a Brazilian motor carrier that had a dedicated transport operation of auto-parts. Moreover the implementation of the model in a specific case, its generic characteristic allows to be applied in others several road transport operations. To assist the development of this model, a review of the papers related to the refueling optimizers was done, and despite the important contributions of these publications, no studies have considered the application in a case study.

In this way, initially we will present a review of existing optimization models, then in the second part the developed model will be described and finally the most relevant final considerations will be expressed. 
This paper is organized in the following way: In Section 1, we present a review of fuel optimizers. In Section 2, we present the methodology, with a description of Transport Operation (2.1), model formulation (2.2), computer solution (2.3) and some adaptations of the model (2.4). In Section 3, we present the results and discussions, followed by the conclusion.

\section{Review of Fuel Optimizers}

Fuel optimizers are decision models to reduce motor carriers fuel costs using information on prices at every gas station within a route. Thus, the optimal fueling schedule for each route is determined, including: (i) which truck stop(s) to use, and (ii) how much fuel to buy at the chosen truck stop(s) to minimize the cost of refueling.

The basic concept of this model is to take advantage of such price variances across truck stops to reduce the total cost of fuel. The model's goal is to buy more fuel at truck stops where the fuel is cheap, and buy less fuel at truck stops where the fuel is expensive. This model normally works combining with truck-routing software, so that users can first compute the optimal (shortest) route for a given origin-destination pair and then optimize the fueling operations along this route.

Research on vehicle refueling has been conducted by both the academic researchers and practitioners. According to Suzuki (2008) most of the early works were conducted by practitioners in the 1990s during the software development phase. These products were designed in order to resolve the concern of many companies that fuel prices fluctuate, sometimes substantially, between a truck stop and the next truck stop in the same route.

Suzuki (2009) lists: (i) ProMiles, (ii) Expert Fuel, and (iii) Fuel \& Route as the most famous fuel optimizer products. Basically, all these applications use mathematical programming models by selecting the optimal locations and quantities of truck stop previously given a route origin and destination. The following factors are the main required inputs by these models: 
- Vehicle tank capacity;

- Average fuel consumption rate for the role trip;

- Retail diesel price;

- Amount of fuel in tank at origin (starting fuel);

- Distance between the truck stop (i) and the next truck stop (i+1);

- Minimum amount of fuel to be maintained in the tank all time;

- Minimum amount of fuel to be refueling.

The majority of these commercial products allow their users to include some restrictions on the model that reflect your corporate preferences so that the solutions become not only possible, but also practical in the point of view of implementation. These specifications can be related to quality aspects of the truck stops or associated to the minimum distance between the truck stops and the route. According to Huff (1997), these applications may require significant adjustments of the optimal solution in order to achieve specific goals for each company.

Despite the proliferation of these kings of software, academic researchers did not study the type of vehicle refueling problem until recently. Suzuki (2009) states that Lin, Gersch and Russel (2007) was the first scholarly paper that considered the refueling problem with focus on total fuel cost. They considered the fix route vehicle refueling problem, similar to that addressed by the commercial fuel optimizers, and developed a linear time greedy algorithm for finding optimal fueling policies. This mentioned algorithm was based on a special case of the inventory capacity lot size problem. In his turn, Lin (2008) extended the work of Lin, Gersch and Russel (2007) by developing an algorithm that jointly define the optimal path (route), and the optimal refueling decisions along the path.

Others papers that has investigated vehicle refueling problems include Khuller, Malekian and Mestre (2007) and Suzuki (2008, 2009). Khuller, Malekian and Mestre (2007) studied several models of vehicle routing problems related to shortest path and traveling-salesman problems. Suzuki (2008) proposed a "generic" approach to the vehicle refueling problem by considering not only the fuel cost, but also several other costs of vehicle operation. On the other hand, 
Suzuki (2009) added new restrictions on the commercial refueling problem aiming to reduce the fuel cost without voiding the freedom of drives to choose truck stops to be used. The author expected to reduce the higher drive turnover rates with this proposed model.

The literature review indicates that earlier studies have made important contributions to the vehicle refueling problems. However, no studies have considered the use of these models in a practical situation showing the real savings.

\section{Methodology}

Aiming to develop, through a case study, a model that meets the characteristics of optimizing refueling policies, the work was divided into three stages. The first stage consisted of gathering information about the transport operation done by the company. At that point, we attempted to obtain information about the technical characteristics of vehicles, total distance, type of routes, number of vehicles, the truck stops and current costs charge in the gas stations.

The second step was to adapt the model, using concepts of linear programming (LP) to the characteristic of the transport operation of the company and, the final stage, consisted of implementing and testing the model using the solver application of Michosoft ${ }^{\circledR}$ Excel. In addition, the necessary adjustments were considered for the model to become applicable to others transport operations with similar characteristics to the proposed work. Finally, we evaluated the financial impact and the indirect benefits generated after applying the model on the route analyzed.

\subsection{Description of Transport Operation}

The problem analyzed was based on a road transport operation of auto-parts from southeast to northeast of Brazil for an automotive industry located on state of Bahia. This operation is complex because it involves a supplying just in time at a distance of approximately $2,000 \mathrm{~km}$ between the place of loading and delivery of cargo.

This transport operation uses 67 dedicated trucks with capacity of 30 tons each. To meet just-in-time system used by the client, it is necessary that the trucks work 24 hours a day, seven days a week and, with the goal of increasing the trucks occupancy, the company has developed 
a methodology of driver exchange which aims to replace the drivers at certain points of the route so as not to let any driver over eight hours behind the wheel, in other words, in this system the driver rests, but the vehicle keeps moving.

The trucks always start from on Southeast region, especially Sao Paulo metropolitan area, where are the main auto parts suppliers, and have the final destination in Camaçari, in the state of Bahia. The main route used is the route that uses the BR381 which pass through Belo Horizonte city and, from this point, goes to the route BR116, as shown in Figure 1.

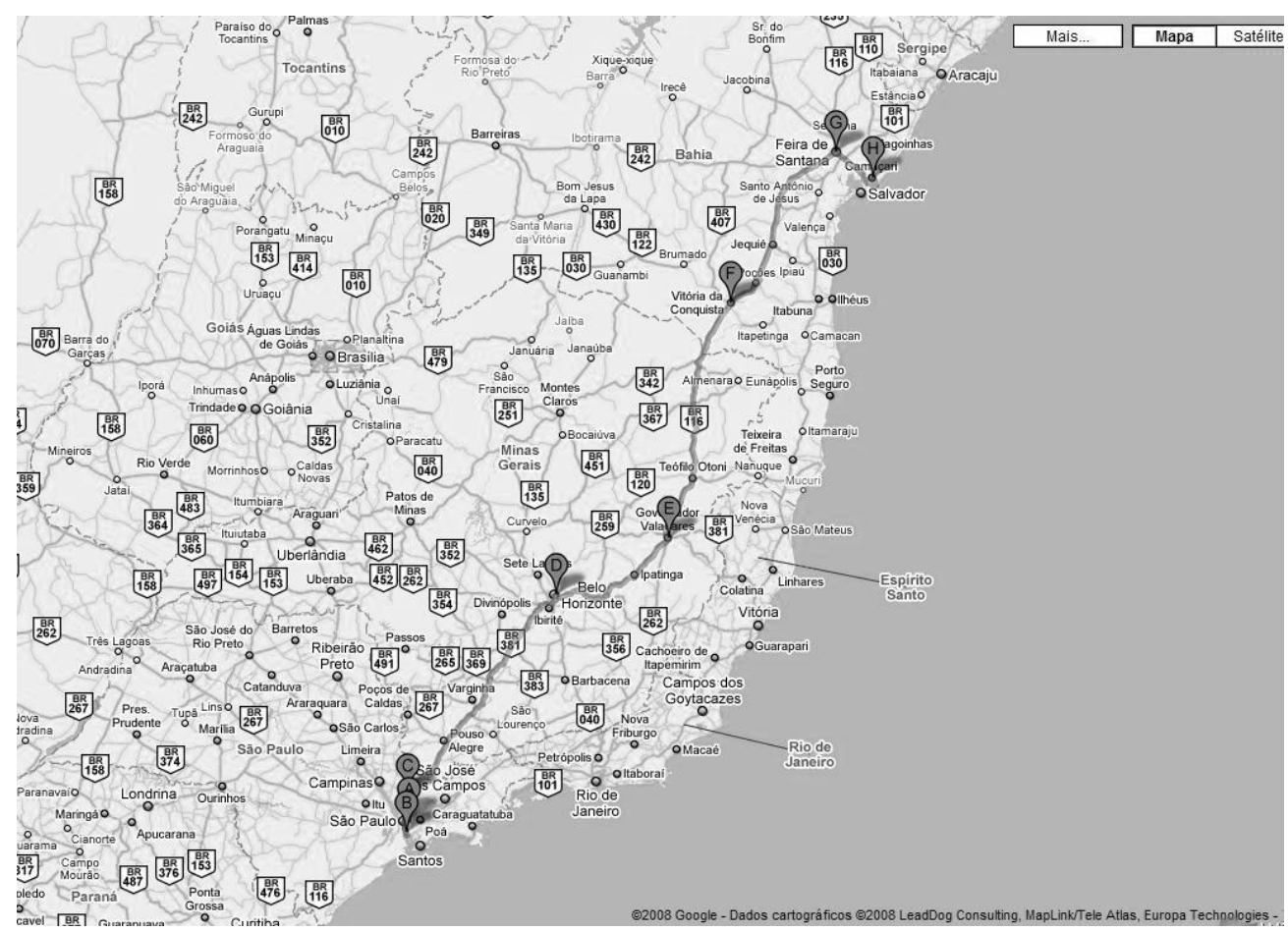

Figure 1 - Main route ${ }^{1}$

The company chose to define the mandatory truck stops on the routes of this operation. At these point, drives exchanges, refueling, preventive maintenance, documents verification and the conference of the load can be performed. The letters A, B, C, D, E, F, G and H highlighted in green in Figure 1 represent the mandatory truck stop.

The A refers to the main point of the operation, where the company's headquarter is located and where the logistics planning is done. From this point, the vehicles follow to the next point B in order to carry the load on suppliers through a logistics system called milk-run. In the milk-run,

${ }^{1}$ Source: Google Maps@. 
in each day the company collects the components from each supplier in predetermined amounts with the goal of delivering those items in a correct time and order for the manufacturer (Greene, 1997).

After completion the collections in suppliers, the trucks goes to the final destination in Camaçari, illustrated by point $\mathrm{H}$ in Figure 1. Along this way, the vehicles pass through the mandatories truck stops (C, D, E, F and G). In order to better explain the route stops, find below the description of each point described in Figure 1:

- Point A: The motor carrier location,

- Point B: The location of auto parts suppliers in the region of Sao Paulo Metropolitan area,

- Point C: Truck stop at Atibaia city (ATB), in the northern of São Paulo,

- Point D: Truck stop at Belo Horizonte city (BHZ),

- Point E: Truck stop at Governador Valadares city (GVD),

- Point F: Truck stop at Vitoria da Conquista city (VDC),

- Point G: Truck stop at Feira de Santana city (FES),

- Point H: Represents the location of the automobile industry, located in the Camaçari city (CAM) in state of Bahia.

According to the company, the main cost of this operation is the fuel. On average, to complete the cycle of the main route each truck uses 2300 liters of diesel. Trucks are constantly supplied at the truck stops, mainly due to capacity limitation in the fuel tank. Each vehicle has two fuel tanks with a capacity of 225 liters each, totaling a storage capacity of 550 liters.

Analyzing the historic supply data of this operation, it was found that there is wide variation in retail diesel prices from the gas stations located in the truck stops and, due to storage capacity of fuel and long distances, it was observed that often the trucks were refueled in the points A, D, E, F and G. In all refueling process it was demanded to fill the tank completely and thus, the vehicle always left the gas station with the tank fully and went to the next point. One of the 
reasons to always fill entirely the truck is to minimize the risk to have some truck stopped on the road for lack of fuel. This fact has become a constraint of the model to be presented in section 2.2. Due to this concern, the company determined that the trucks in this operation could not have less than 50 liters of fuel tank at any point of their routes.

After this stage of rising information about the transport operation, we elaborated a mathematical model to determine the ideal amount of fuel to be supplied at each truck stop in order to minimize the total cost so that the capacity refueling constraints must to be met. In addition, other restrictions were considered, such as autonomy between the truck stops and minimum quantity in liters in the tank.

\subsection{Model Formulation}

The model is based on the basic concepts of refueling optimizers witch goal is to minimize the total fuel cost in the transport operation. In this model, routes must be fixed and the truck stops need to be previously defined. Logistics constraints of this operation and technical characteristics of vehicles are the input variables of the model. The total fuel amounts to be supplied at each truck stop are the output figures.

Index:

- $\quad \mathrm{i}=$ index of stop points.

- Variables:

- $\mathrm{q}_{\mathrm{i}}=$ quantity of fuel supplied at point $\mathrm{i}$ on the trip to the first destiny,

- $\quad \mathrm{q}_{\mathrm{i}}{ }_{\mathrm{i}}=$ quantity of fuel supplied at point $\mathrm{i}$ on the way back,

- $v_{i}=$ quantity of fuel on tank at the point $\mathrm{i}$ on the trip to the first destiny,

- $\quad \mathrm{v}_{\mathrm{i}}{ }_{\mathrm{i}}=$ quantity of fuel on tank at the point $\mathrm{i}$ on the way back,

- $\quad \mathrm{Z}=$ fuel total costs. 


\section{Constants:}

- $c_{i}=$ fuel price $(\mathrm{R} \$ /$ liters $)$ at point $\mathrm{i}$,

- $\mathrm{d}_{\mathrm{i}, \mathrm{i}+1}=$ distance from point $\mathrm{i}$ to the next point $(\mathrm{i}+1)$,

- $\mathrm{k}=$ average consumption rate $(\mathrm{km} / \mathrm{l})$,

- $\quad$ Q = fuel tank capacity (liters),

- $S=$ minimum acceptable quantity in the tank (security constraint).

Find below the graphical representation of the model:

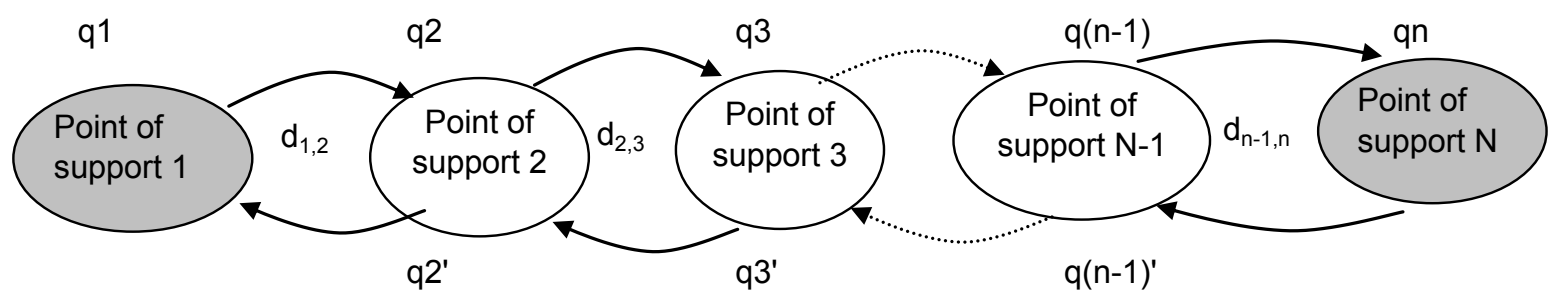

Figure 2: Graphical representation of a fixed route with $\mathrm{N}$ truck stops ${ }^{2}$

This model can be mathematical defined like:

$$
\operatorname{Min} \mathrm{Z}=\sum_{1}^{n} c_{i} q_{i}+\sum_{1}^{n} c_{i} q_{i}^{\prime}
$$

$\mathrm{n}=$ quantity of truck-stops

Subject to:

Safety constraint:

$$
\begin{aligned}
& \mathrm{v}_{\mathrm{i}}+\mathrm{q}_{\mathrm{i}}-\left(\mathrm{d}_{\mathrm{i},{ }_{\mathrm{i}+1}}\right) / \mathrm{k} \geq \mathrm{S} \quad \forall 1 \leq \mathrm{i}<(\mathrm{n}-1) \\
& \mathrm{v}_{\mathrm{i}}^{\prime}+\mathrm{q}_{\mathrm{i}}^{\prime}-\left(\mathrm{d}_{\mathrm{i}-1},{ }_{\mathrm{i}}\right) / \mathrm{k} \geq \mathrm{S} \quad \forall 2 \leq \mathrm{i}<\mathrm{n}
\end{aligned}
$$

\footnotetext{
${ }^{2}$ Source: the authors.
} 
Fuel tank capacity constraint:

$$
\begin{aligned}
& \mathrm{v}_{\mathrm{i}}+\mathrm{q}_{\mathrm{i}} \leq \mathrm{Q} \quad \forall \mathrm{i} \in \mathrm{n} \\
& \mathrm{v}_{\mathrm{i}}^{\prime}+\mathrm{q}_{\mathrm{i}}^{\prime} \leq \mathrm{Q} \quad \forall \mathrm{i} \in \mathrm{n}
\end{aligned}
$$

Optional constraint:

$$
\mathrm{v}_{1}^{\prime}=\mathrm{S}
$$

Nonnegativity constraint:

$$
\begin{aligned}
& \mathrm{q}_{\mathrm{i}} \geq 0 \\
& \mathrm{q}_{\mathrm{i}}^{\prime} \geq 0
\end{aligned}
$$

Equation (1) is the objective function to be minimized and represents the total fuel cost considering the complete cycle route. The constraints of the model are represented by equations (2) to (8). Equations (2) and (3) are the safety constraints of the model. The number (2) ensures that the vehicle will always have a minimum of $\mathrm{S}$ liters of fuel in the tank when it moves from origin to final destination. The constraint (3) guarantees this same minimum quantity $\mathrm{S}$ in the tank of the vehicle when the vehicle returns to the origin.

The constraints of a maximum capacity of fuel tanks are described in (4) and (5). Constraint (4) guarantees the maximum fuel when the vehicle moves from origin to destination and the equation (5) ensures the limit to the return of the vehicle. The constraint (6) guarantees that the truck will finish the cycle with the tank full. This constraint can be removed or changed according each transport characteristics.

To complete the model it is necessary to add the restrictions (7) and (8) of nonnegativity, so there is no negative refueling. 


\subsection{Computer Solution}

Aiming to facilitate the use of the proposed model, we used the Solver tool, available in Microsoft ${ }^{\circledR}$ Excel application, in order to solve the model developed. Subsequently we have created a spreadsheet composed of two parts, the first one for the input data and the second one for the output data. For the input, the analyst must enter the data of possible points of support or truck-stops that can be done the refueling process, the points of origin and the destination of the cargo, the distances between the truck stops, the maximum fuel capacity in liters, the cost per liter of each gas station and fuel average consumption rate. The Table 1 below illustrates the input data, distances and fuel costs in the truck stops of the mentioned route.

Table 1 - Input data $^{3}$

\begin{tabular}{c|ccccc}
\hline $\mathbf{i}$ & Origin & $\mathbf{j}$ & Destination & Distance $(\mathbf{K m})$ & Fuel Price $\left(\mathbf{c}_{\mathbf{i}}\right)$ \\
\hline 1 & SAO & 2 & ATB & 134 & $\mathrm{R} \$ 1,83$ \\
2 & ATB & 3 & BHZ & 560 & $\mathrm{R} \$ 2,11$ \\
3 & BHZ & 4 & GVD & 315 & $\mathrm{R} \$ 2,10$ \\
4 & GVD & 5 & VDC & 524 & $\mathrm{R} \$ 2,02$ \\
5 & VDC & 6 & FES & 398 & $\mathrm{R} \$ 1,98$ \\
6 & FES & 7 & CAM & 140 & $\mathrm{R} \$ 1,84$ \\
7 & CAM & & & & $\mathrm{R} \$ 2,06$ \\
\hline
\end{tabular}

In the second part of the worksheet, the output information is presented only after the application of the Solver parameterized with the characteristics of the model of the section 2.2. Basically, the mainly output information of the model are: the truck stops that will be done the refueling, the optimal quantity of fuel to be supplied at these points and the total operation cost to fuel.

A new scenario should be recalculated whenever there are changes in gas station prices in the transport operation. These prices update could be done by the drivers themselves during the travel or using specialized websites.

\footnotetext{
${ }^{3}$ Source: authors' own calculations.
} 
Table 2 - Output data ${ }^{4}$

\begin{tabular}{|c|c|c|c|c|c|c|}
\hline$\overline{\mathbf{i}}$ & $\begin{array}{c}\text { Truck } \\
\text { stop }\end{array}$ & $\mathrm{R} \$ /$ Liters & $\begin{array}{l}\text { Quantity } \\
\text { of fuel in } \\
\text { the tank }\end{array}$ & $\begin{array}{c}\text { Refueling } \\
\text { quantity }\end{array}$ & $\begin{array}{c}\text { Total } \\
\text { quantity }\end{array}$ & $\begin{array}{c}\text { Total Cost } \\
\text { (BRL) }\end{array}$ \\
\hline 1 & SAO & $\mathrm{R} \$ 1,83$ & 550 & - & 550 & $\mathrm{R} \$$ - \\
\hline 2 & ATB & $\mathrm{R} \$ 2,11$ & 476 & - & 476 & $\mathrm{R} \$$ - \\
\hline 3 & BHZ & $\mathrm{R} \$ 2,10$ & 164 & 61 & 225 & $\mathrm{R} \$ 127$ \\
\hline 4 & GVD & $\mathrm{R} \$ 2,02$ & 50 & 291 & 341 & $\mathrm{R} \$ 588$ \\
\hline 5 & VDC & $\mathrm{R} \$ 1,98$ & 50 & 221 & 271 & $\mathrm{R} \$ 438$ \\
\hline 6 & FES & $\mathrm{R} \$ 1,84$ & 50 & 500 & 550 & $\mathrm{R} \$ 920$ \\
\hline 7 & CAM & $\mathrm{R} \$ 2,06$ & 472 & - & 472 & $\mathrm{R} \$$ - \\
\hline 6 & FES & $\mathrm{R} \$ 1,84$ & 394 & 156 & 550 & $\mathrm{R} \$ 286$ \\
\hline 5 & VDC & $\mathrm{R} \$ 1,98$ & 329 & 221 & 550 & $\mathrm{R} \$ 438$ \\
\hline 4 & GVD & $\mathrm{R} \$ 2,02$ & 259 & 291 & 550 & $\mathrm{R} \$ 588$ \\
\hline 3 & $\mathrm{BHZ}$ & $\mathrm{R} \$ 2,10$ & 375 & 61 & 436 & $\mathrm{R} \$ 127$ \\
\hline 2 & АTB & $\mathrm{R} \$ 2,11$ & 124 & - & 124 & $\mathrm{R} \$-$ \\
\hline 1 & SAO & $\mathrm{R} \$ 1,83$ & 50 & 500 & 550 & $\mathrm{R} \$ 915$ \\
\hline Total & & & & 2.301 & & $\mathrm{R} \$ \mathbf{4 . 4 2 7}$ \\
\hline
\end{tabular}

\subsection{Adaptations of the model}

The optimization model of refueling policies proposed in this paper could be applied to any dedicated transport operations involving the movement of trucks on a fixed route. However, some modifications may be made to better adjust the model to the reality of the operation.

In some routes, mainly due to the different types of topography and road quality, there are substantial differences in fuel consumption rate. In this case it is necessary to consider the average of fuel consumption rate $(\mathrm{k})$ for each displacement between the truck stops. Thus, constraints (2) and (3) presented in section 2.2, would be as follows:

\footnotetext{
${ }^{4}$ Source: authors' own calculations.
} 


$$
\begin{aligned}
& \mathrm{v}_{\mathrm{i}}+\mathrm{q}_{\mathrm{i}}-\left(\mathrm{d}_{\mathrm{i}, \mathrm{i}+1}\right) / \mathrm{k}_{\mathrm{i}} \geq \mathrm{S} \quad \forall \quad \mathbf{1} \leq \mathbf{i}<(\mathbf{n}-\mathbf{1}) \\
& \mathrm{v}_{\mathrm{i}}+\mathrm{q}_{\mathrm{i}}^{\prime}-\left(\mathrm{d}_{\mathrm{i}-1, \mathrm{i}}\right) / \mathrm{k}_{\mathrm{i}} \geq \mathrm{S} \quad \forall \quad \mathbf{2} \leq \mathbf{i}<\mathbf{n}
\end{aligned}
$$

\section{Results and Discussions}

The considered model was used to carry through the optimization of the refueling politcies in the transport operations of auto parts analyzed. To verify the effectiveness of this model there were collected information about truck stops, amount of supplied fuel as well the fuel cost in each fuel station before the implementation of the model. Based on this information, it was observed that the vehicles always were supplied in A, D, E, F and G, as described in the section 2.1 and that the refueling was always completed, what means that the vehicle left the fuel station with the complete tank.

After this first analysis, the total cost of the fuel spent by each vehicle, before the application of the model, was compared with the total fuel cost per vehicle after the implementation. The Table 3 compares the refueling policies before and after the use of the model proposed.

When comparing the current refueling policy, before the application of the optimization model, with the new policy recommended by the model, significant differences in the amounts refueled can be observed in specific fuel stations. In the station $\mathrm{D}$, for example, a difference of 440 liters for trips was observed. Those differences, when multiplied for the cost of the fuel of each truck stop, had generated a fuel economy of 104 BRL (Brazilian Reals) by each vehicle in the analysis.

This value represents the reduction of $2,3 \%$ in the total cost of fuel and, based on the daily average amount of trips completed in the route analized ( 8 trips per day, 240 per month), we estimated that in one year the value saved with the application of the optimization model would be approximately 300,000 BRL. 
Table 3 - Comparisons between the current refueling policy and the model proposal ${ }^{5}$

\begin{tabular}{c|cc|cc}
\hline & \multicolumn{2}{|l|}{ Current situation } & \multicolumn{2}{l}{ After the use of proposed model } \\
\hline Truck Stop & Refueling Quantity & Cost & $\begin{array}{c}\text { Refueling } \\
\text { Quantity }\end{array}$ & Costs \\
\hline A & 386 & $\mathrm{R} \$ 706$ & 500 & $\mathrm{R} \$ 915$ \\
B & - & - & - & - \\
C & - & - & - & - \\
D & 561 & $\mathrm{R} \$ 1.177$ & 121 & $\mathrm{R} \$ 254$ \\
E & 466 & $\mathrm{R} \$ 942$ & 582 & $\mathrm{R} \$ 1.176$ \\
F & 512 & $\mathrm{R} \$ 1.014$ & 442 & $\mathrm{R} \$ 876$ \\
G & 377 & $\mathrm{R} \$ 693$ & 656 & $\mathrm{R} \$ 1.206$ \\
H & - & - & - & - \\
Total & $\mathbf{2 . 3 0 2}$ & $\mathbf{R} \$ \mathbf{4 . 5 3 2}$ & $\mathbf{2 . 3 0 1}$ & $\mathbf{R} \$ \mathbf{4 . 4 2 7}$ \\
\hline
\end{tabular}

\section{Conclusion}

This paper aproachs the planning of the transport to the refueling policies of trucks for motor carriers. A generic linear optimization model was developed and applied in a case study. In addtition to that, the company current refueling policies was compared to the model proposal and a important reduction was observed in the second situation, which implies a reduction of the total cost of the transport. Furthermore, the model could be considered flexible to be adapted to differents transport operations.

A limitation of the considered model is that it assumes that vehicle has a predetermined route before the beginning of the operation of transport. So, for each change in the original route, a new scenario shoud be run as well as the change of the original data. Therefore, an interesting extension to this paper could be the addition of vehicle routing programs with the refueling optmizers models.

${ }^{5}$ Source: authors' own calculations. 


\section{References}

Associação Nacional do Petróleo - ANP (2010) Levantamento de Preços e de Margens de Comercialização de Combustíveis. 2010. Available: www.anp.gov.br. Acessed: Jan 2011.

Greene, J. H. (1997) Production and Inventory Control Handbook. McGraw-Hill, Nova Iorque. Huff, A. (1997) Tech in Focus: Fuel Optimization. CJ Commercial Carrier Journal. Available at www.ccjdigital.com. Accessed: Apr 2010.

Khuller, S., Malekian, A. and Mestre, J. (2007) To Fill or Not to Fill: The Gas Station Problem. Algorithms - ESA, pp. 534-545.

Lima. M. P. (2006) Custos Logísticos na Economia Brasileira. Revista Tecnologística, Rio de Janeiro.

Lin, S. H. (2008) Finding Optimal Refueling Policies in Transportation Networks. Algorithmic Aspects in Information and Management, Finding Optimal Refueling Policies in Transportation Networks, vol. 5034, pp. 280-291.

Lin, S. H., Gertsch, N. and Russell, J.R. (2007) A linear-time algorithm for finding optimal vehicle refueling policies. Operations Research Letters, vol. 35, n.3, pp.290-296.

Lopes, S., Cardoso, M. and Piccinni, M. (2008) O transporte rodoviário de carga e o papel do BNDES. Revista do BNDES, vol. 14, n. 29, pp. 35-60.

Nazário, P. (2000) Papel do Transporte na Estratégia Logística. Logística empresarial, São Paulo: Atlas.

Rittiner, D. and Manechini, G. (2009) Queda do diesel não garante frete menor. Valor Econômico. Available at conteudoclippingmp.planejamento.gov.br. Accessed: jun 2009.

Suzuki, Y. (2008) A generic model of motor-carrier fuel optimization. Naval Research Logistics, vol. 55 , n. 8, pp. 737-746.

Suzuki, Y. (2009) A decision support system of dynamic vehicle refueling. Decision Support Systems, vol. 46, n. 2, pp. 522-531. 